\title{
Assessing the quality of water used by the community of Madlangamphisi in the Hhohho region of Eswatini
}

\author{
Dlamini, M. V.*; Manyatsi, A. M. and Dlamini, K. A.
}

Dept. of Agricultural and Biosystems Engineering, University of Eswatini, Faculty of Agriculture, Private Bag, Luyengo, Eswatini. *Corresponding Author: musavd@uniswa.sz or musavd@gmail.com.

\begin{abstract}
Clean water is necessary for communities. However, in some communities water is obtained from various sources which potentially can cause a health hazard. The research was conducted to assess the quality of domestic water used by the community of Madlangamphisi area in the Hhohho district of Eswatini. A questionnaire and physical water sampling were used to collect both the qualitative and quantitative data reported in this paper. Water samples to determine the quality of water used for domestic purposes in the area were taken from the common sources, the community borehole and the Nkomazi river. The samples were tested for microbial water quality and the Eswatini Water Services Corporation drinking water guidelines used as the bench mark. A total of 169 households out of 300 households were randomly selected to participate in the survey. The majority (51.5\%) of the households used water from the river, $24.9 \%$ used water from the borehole, $18.3 \%$ depended on rainfall and $5.3 \%$ used water from seasonal streams. Water analysis results revealed that water from the river was polluted, as it contained $8 / 100 \mathrm{ml}$ of faecal coliforms (E. coli) which was higher than $0 / 100 \mathrm{ml}$ recommended in the benchmark. The water from the borehole did not contain E. coli. The majority (56.2\%) of the households did not purify the water before use, 27.2\% added bleach, $12.4 \%$ used boiling and $4.1 \%$ used treatment sachets for purifying the water. The study concluded that Madlangamphisi community faced a serious risk of water borne diseasese specially faecal coliforms (E. coli).The study observed that there is a need to introduce a rural water supply scheme in the area to solve the water quality problemsto avoid a potential outbreak of diseases.
\end{abstract}

Keywords-Community, water, rural schemes, faecal coliforms, water quality.

\section{INTRODUCTION}

Water is a valuable life commodity (Chaplin, 2001)that supports numerous ecosystems. It is absolutely essential not only for survival of human beings, but also for animals, plants and all other living things (Razo et al., 2004).It is however becoming a scarce resource (Khalifa and Bidaisee, 2018) in most parts of the world, partly due to global warming which results to drought conditions and mismanagement by humans (Srinivasan, et.al., 2012). Water pollution and wasteful use of freshwater are threatening development projects, making water treatment an indispensable requirement to produce safe drinkingwater (Helmer, 1994).Water of good quality is a crucial key to sustainable socio-economic development.

In a model of water quality selection described by Carrie and Genevieve (2007) the protection of source water quality for domestic use (drinking water, abstraction etc.) was identified by most experts' group as a priority for assessment.
Eswatini is one of the countries that have an average number of water sources which includes dams, rivers, groundwater, wetlands, springs and streams (Manyatsi and Brown, 2009) to name a few, yet the supply of water is insufficient. It has been observed that the most important challenge facing the South African Food Energy Water Nexus is water quality (Oberholster and Botha, 2014). Most domestic water is obtained from rivers that have been reported to contain high levels of microbial pollutants (especially E. coli) which can act as a vehicle for food contamination (Genthe et al. 2013).

Meals (2001) suggested that a combination of vegetated buffer strips and riparian zones shows a significant decline in microbial counts. Riparian zones are naturally occurring within the flood area of rivers or streams and need to be protected to improve downstream ecosystem services. River water quality is a key concern as it is used for drinking and domestic purpose, irrigation and aquatic life including fish and fisheries (Uddin, et al., 2014). 
On the other hand, polluted water is the greatest source of disease and besides debasing the land also becomes unfit to sustain life (Khalifaand Bidaisee, 2018). Natural waters are afflicted with a wide variety of inorganic, organic, and biological pollutants. The increased application of commercial fertilizer and widespread use of a variety of new pesticides (insecticides, nematicides, herbicides and weed killers) in agricultural practices are resulting in a host of new pollution problems from land drainage. This type of agricultural pollution has severe impact on water Pollution, as most of pollutants are resistant to natural degradation. Although concentration of the pollutants are still rather low, many of this compounds are toxic to human or animal life; some of them are carcinogenic or have serious ecological contamination (Davis and Cornwell,1998; Peavy, et al, 1985; Sawyer, et al., 1994).To add to the contamination from humans and animals, nature itself can contaminate the water and make it unusable, however many populations are forced to use these unsafe water sources (Lenntech, 2016). The two main factors that hold communities back from their bright futures are illnesses from drinking unsafe water and the time required in fetching water due to access being an issue (The Water Project, 2016). If clean water becomes more accessible for populations, it can be safe to assume that health will also increase; this in turn will decrease the time lost to sickness.

More than five million people die each year from diseases caused by unsafe drinking water, lack of sanitation, and insufficient water for hygiene. In fact, over two million deaths occur each year from water-related diarrhoea alone. At any given time, almost half of the people in developing countries suffer from water-related diseases (Gleick, 2002). Every dayit is estimated that one thousand lives of children are taken from illnesses like diarrhoea, dysentery, and cholera because of unclean water and unhygienic living conditions.

\section{MATERIALS AND METHODS}

Madlangamphisi is an area in the Hhohho district of Eswatini located at $26^{\circ} 05^{\prime} 22.70^{\prime \prime} \mathrm{S}$ and $31^{\circ} 32^{\prime} 59.52^{\prime \prime} \mathrm{E}$ at an elevation of $397 \mathrm{~m}$ above sea level. It is a community of about 300 households. A questionnaire was administered to members of the community to help in the collection of both qualitative and quantitative data, 169 households were selected with $95 \%$ confidence level and 5\% margin of error. Water samples from a community borehole and the
Nkomazi River (used as sources of water)were collected and then tested in a certified laboratory to obtain water quality results, mainly Escherichia coli. The Eswatini Water Services Corporationand the World Health Organization (WHO) drinking water guidelines were used as a benchmark for the water quality tests.

The daily water consumption for the household was estimated using the following equation.

Daily Water Consumption $=$

Total amount used in household per day

Number of people in the household

\section{RESULTS AND DISCUSSIONS}

\section{Demographic information}

The number of people per household (Table 1) were categorized into four groups: 1 to 3 people, 4 to 7 people, 8 to 10 people and 11 to 14 people. A majority of the households $46.2 \%$ had 4 to 7 family members. This showed a high population density, and this indicated that the area had a high domestic water demand. According to Jaeger(2012) when the population is high water scarcity arises as the demand grows beyond the available supply and is mainly limited by physical availability of water. The number of people per household was used to calculate the daily water requirements of each of the households.

Table 1: The number, frequency and percentage of people per household in the sample surveyed $(N=169)$.

\begin{tabular}{cll}
\hline $\begin{array}{l}\text { Number of people } \\
\text { per household }\end{array}$ & Frequency & $\begin{array}{l}\text { Percent } \\
(\%)\end{array}$ \\
\hline $1-3$ & 52 & 30.8 \\
$4-7$ & 78 & 46.2 \\
$8-10$ & 29 & 17.2 \\
$11-14$ & 10 & 5.9 \\
Total & 169 & 100.0 \\
\hline
\end{tabular}

A presentation of the length of stay for the households in the Madlangamphisiarea is illustrated in Figure 1. A majority $(74 \%)$ of the households had been staying in the area for more than ten years, and only less than three percent had been in the area for more than 50 years. This shows that the information provided about the status of water availability or scarcity was reliable, as the people are well versed and have experienced on all water related issues in the area. 


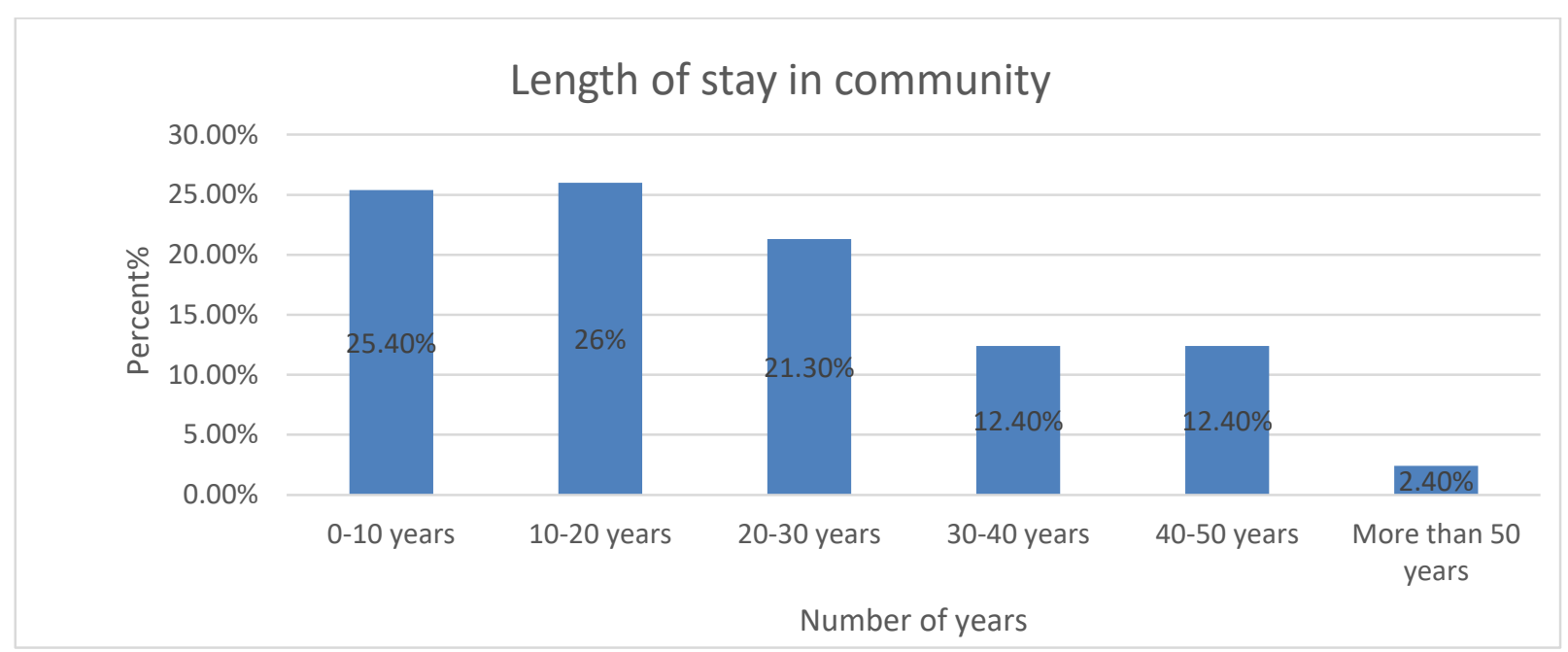

Fig.1: Residence time of the households in Madlangamphisi community

\section{Domestic water sources}

The various sources of domestic water at Madlangamphisi are shown in Table 2.The majority $51.5 \%$ of the households in the community used the Nkomazi river as their main source of water for domestic use, while $24.9 \%$ of the households use a community borehole and $18.3 \%$ use harvested rainwater and only $5.3 \%$ used seasonal streams. The Nkomazi river and community boreholes were found to be the main water sources. The Nkomazi river was preferred by most of the households since it does not dry up even during dry seasons, hence it is a reliable source of water. Other minor alternative sources of water included buying water from shops specifically used for drinking since it was bought in small quantities.

Table 2: Sources of domestic water used by Madlangamphisi households $(N=169)$

\begin{tabular}{lll}
\hline Water sources & Frequency & $\begin{array}{l}\text { Percent } \\
(\%)\end{array}$ \\
\hline Borehole & 42 & 24.9 \\
River & 87 & 51.5 \\
Seasonal streams & 9 & 5.3 \\
Rainwater & 31 & 18.3 \\
Total & $\mathbf{1 6 9}$ & $\mathbf{1 0 0 . 0}$ \\
\hline
\end{tabular}

Although some of the households used harvested rainwater and streams, they still depended on the community borehole and the Nkomazi River since they could not depend on the unreliable rainfall. The results showed that a majority $(56.8 \%)$ of the households relied on unprotected water sources, as their main water sources were the river and streams. Water from these sources particularly the river and seasonal streams was exposed to contamination owing to the fact that surface water sources were prone to being polluted. This means that the households were more vulnerable to infection by waterborne diseases.

\section{Water quality results}

The outcome of a survey of the residence on the perception of the quality of the water is shown in Table 3 . A majority, $63.9 \%$ of the population perceived the water to contain some soil sediments and solid waste. Only $36.1 \%$ of the population used clean water which they obtained from the borehole and rainwater. As the majority of the households used unsafe, dirty water when asked if they purified the water, $56.2 \%$ responded negatively.

Those households that treated the water use either one of the following methods: boiling (12.4\%), adding bleach (27.2\%) and use the P\&G water treatment sachets is $4.1 \%$. The $56.2 \%$ of the residents which did not treat the water are more vulnerable to waterborne disease because the water they used was contaminated.

Table 3: Perception of households on the water quality and method of treatment $(N=169)$

\begin{tabular}{llll}
\hline Water quality & & Frequency & $\begin{array}{l}\text { Percent } \\
(\%)\end{array}$ \\
\hline Is water clean & Yes & 61 & 36.1 \\
& No & 108 & 63.9 \\
& Total & 169 & 100.0
\end{tabular}




$\begin{array}{lllll}\text { Treatment } & \text { used to clean } & \text { Boiling } & 21 & 12.4 \\ \text { water } & & \text { Adding bleach } & 46 & 27.2 \\ & & \text { Use P\&G } \quad \text { water } & \\ & \text { treatment sachets } & 7 & 4.1 \\ & \text { None } & 95 & 56.2 \\ & \text { Total } & 169 & 100.0\end{array}$

\section{Faecal coliforms in groundwater}

Table 4 shows the level of E.coli bacteria found in borehole and river water. No E.coli was detected in borehole water at Madlangemphisi, meaning that it was safe for drinking.

Table 4: E. colicounts in groundwater and surface water

\begin{tabular}{lccc}
\hline Source of water sample & Samples & E.coli $($ counts/100 ml) & \\
\hline \multirow{2}{*}{ Borehole } & 1 & 0 \\
& 2 & 0 \\
Nkomazi & Mean & 0 \\
& 1 & 7 \\
& 2 & 9
\end{tabular}

Mean 8

The water sourced from the Nkomazi river was contaminated with $E$. coli. The first sample results indicated $(7 / 100 \mathrm{ml})$ while the second results reflected $(9 / 100 \mathrm{ml})$ E. coli presence. This meant that water sourced from Nkomazi River was not suitable for domestic use as it was more than the WHO water standards guidelines. However, the values were within the standards set by the Government of Eswatini for rural water (Government of Swaziland, 1998). The Nkomazi river is a surface water source which is unprotected, making the water vulnerable to contamination from human waste through open defecation and animal waste. The community has some farmers who kept livestock, that also used water from the Nkomazi river. The faecal coliform counts detected from the water of the Nkomazi river showed that the majority of the residents used water that was contaminated thus of poor quality making them potentially vulnerable to waterborne diseases.

\section{Incidence of water borne diseases at Madlangamphisi}

When responding to the incidences of water borne diseases (Table 5), 60.9\% reported that they had no incidences of waterborne diseases for the past year (2017) and 39.1\% households have had incidences of water borne diseases. This was due to the use of untreated water, and storing of rainwater for a long time. The rainwater after sometime, is said to contain microbes which may cause cholera as reported by $18.9 \%$ and rashes $11.2 \%$ of the households. Those using untreated water from the river usually suffered from bilharzia $8.3 \%$ with $0.6 \%$ suffering from bladder infections.

Table 5: Water borne diseases experienced by households in the area $(N=169)$

\begin{tabular}{llll}
\hline Waterborne diseases & & Frequency & Percent \\
\hline Incidences & Yes & 66 & 39.1 \\
& No & 103 & 60.9 \\
& Total & 169 & 100.0 \\
Types of diseases & Bilharzia & 14 & 8.3 \\
& Rash & 19 & 11.2 \\
& Cholera & 32 & 18.9 \\
& Bladder infection & 1 & 0.6 \\
& Total & 66 & 39.1 \\
& None & 103 & 60.9 \\
& Total & 169 & 100.0 \\
\hline
\end{tabular}




\section{CONCLUSION}

From the study, it was noted that the majority $63.9 \%$ of the households relied on unsafe drinking water for domestic use and that $56.2 \%$ of the households did not purify the water before use. The water quality tests indicated that water sourced from the Nkomazi River was contaminated with feacal coliforms $(8 / 100 \mathrm{ml})$, making its water unsuitable for domestic use. The community therefore faced a serious risk of water borne diseases. $39.1 \%$ of the households reported to have had an incidence of disease, mostly cholera, rash, and bilharzia.It was concluded that there was a need to introduce a rural water supply scheme in the area to help solve the water quality problems.

\section{REFERENCES}

[1] Carrie, R. and Genevieve, M. C. (2007). Global water drinking water quality index development and sensitivity anaylsis report. United Nations Environment Programme Global Environment Monitoring System (GEMS) / Water Programme. P60.

[2] Chaplin, M. F. (2001). Water: its importance to life. Biochemistry and Molecular Biology Education 29 (2001): 54-59

[3] Davis, M.L. and Cornwell, D.A. (1998). Introduction to Environmental Engineering, third edition, McGraw Hill Book Company.USA. pp289-297

[4] Genthe, B., Le Roux, W.W.J., Schachtschneider, K., Oberholster, P.J., Aneck-Hahn, N.H. and J. Chamier. (2013). Health risk implications from simultaneous exposure to multiple environmental contaminants. Ecotoxicol Environ Saf:2013: 93:171 - 179.

[5] Gleick, P. H. (2002).Dirty Water:Estimated Deaths from Water-Related Diseases 2000-2020. Pacific Institute Research Report. 1-12.

[6] Government of Swaziland. (1998). Rural water quality guidelines and rationale: case study from Swaziland. Development Bank of Southern Africa. www.dbsa.org.za/document/pdevtoday/rural $\% 20$ water $\% 20$ quality $\% 20$ (devtoday\%20jan06).doc

[7] Helmer, R. (1994). Water quality monitoring: national and international approaches. Hydrological, Chemical and Biological Processes of Transformation and Transport of Contaminants in Aquatic. Environments (Proceedings of the Rostov-on-Don Symposium, May 1993). IAHSPubl. no. 219, 1994.

[8] Jaeger, W., Plantinga, J., and Chang, H. (2012). Towards a formal definition of water scarcity in natural-human systems. Water Resources Research, vol.49, 4506 - 4517.

[9] Khalifa, M. and Bidaisee, S. (2018). The Importance of Clean Water. Sch J ApplSci Res. Vol: 1, Issu: 7 (17-20).

[10] Lenntech. (2016). Water treatment \& purification: water Borne diseases. www.lenntech.com

[11] Manyatsi, A. M, and Brown, R. (2009). IWRM Survey and Status Report: Swaziland. Global Water Partnership Southern Africa.
[12] Meals, D.W. (2001). Water quality response to riparian restoration in an agricultural watershed in Vermont, USA. Water Science and Technology 43: 175-182.

[13] Oberholster, P.J. and Botha, A. M. (2014). Importance of water quality to the food industry in South Africa. Understanding the Food Energy Water Nexus. WWF-SA, South Africa.

[14] Peavy, H.S.; Rowe, D.R. and Technology, G. (1985). Environmental Engineering McGraw Hill Publishing Company Ltd. pp11-46.

[15] Razo, I.,Carrizales, L., Castro, J., Diaz, B. F. and Moroy, M. (2004).Arsenic and Heavy Metal Pollution of Soil, Water and Sediments in a semi-arid Climate Mining area in Mexico. Water, Air, Soil Poll., 152 (1-4): 129-152.

[16] Sawyer, C.L., McCarthy, P.L., and Parkin, G.F. (1994). Chemistry for Environmental Engineering Fourth edition, McGraw Hill Book Company, p545.

[17] Srinivasan, V., Lambin, E. F., Gorelick, S. M., Thompson, B. H., and Rozelle, S. (2012). The nature and causes of global water crisis: Syndromes from a meta-analysis of compled human-water studies. Water Resources Research journal, vol. $48: 1-16$.

[18] The Water Project. (2016). Global Water Shortage: Water Scarcity \& the Importance of Water. United Nations Synthesis Report on Arsenic in Drinking Water.

[19] Uddin, M. N., Alam, M. S., Mobin, M. N., and Miah, M. A. (2014). An assessment of the river water quality parameters: A case of Jamunariver. J. Environ. Sci. \& Natural Resources, 7(1): $249-256$. 